\title{
Decadal persistence of frugivorous birds in tropical forest fragments of northern Paraná
}

\author{
Tiago Zaiden ${ }^{1}$, Fernanda Cristina Marques ${ }^{1,2}$, Hugo Reis Medeiros ${ }^{1}$ \& Luiz dos Anjos ${ }^{1}$ \\ ${ }^{1}$ Universidade Estadual de Londrina, Programa de Pós Graduação em Ciências Biológicas, CP 6001, \\ CEP 86051-990, Londrina, PR, Brazil. \\ ${ }^{2}$ Corresponding author: Fernanda Cristina Marques, e-mail: fernanda1081@gmail.com
}

\begin{abstract}
ZAIDEN, T., MARQUES, F.C., MEDEIROS, H.R., ANJOS, L. Decadal persistence of frugivorous birds in tropical forest fragments of northern Paraná. Biota Neotropica. 15(2): e20140084. http://dx.doi. org/10.1590/1676-06032015008414
\end{abstract}

\begin{abstract}
Forest fragmentation is a major cause of loss of species. We evaluated the local extinction of medium-large frugivorous bird species in six forest fragments of northern Paraná: the Parque Estadual Mata dos Godoy (PEMG), the largest and most preserved forest fragment in the region, and five other fragments. Fixed-width point counts and line transects were conducted along trails in the PEMG for 10 days: from September 2010 to March 2011, and from August 2011 to November 2011. Avian surveys in each of the other forest fragments were made over four days from October to December 2011. We compared data with a previous census carried out 10 years earlier. No extinction events were recorded from the PEMG. However, the relative abundance of species significantly changed during the ten years between surveys. In all the other forest fragments at least two frugivorous bird species disappeared, and in some as many as seven. Protecting the PEMG is crucial for the maintenance of frugivorous bird populations in our studied landscape. Keywords: forest fragmentation, large frugivorous birds, extinction debit.
\end{abstract}

ZAIDEN, T., MARQUES, F.C., MEDEIROS, H.R., ANJOS, L. Persistência de aves frugívoras após uma década em fragmentos florestais do norte do Paraná. Biota Neotropica. 15(2): e20140084. http://dx. doi.org/10.1590/1676-06032015008414

Resumo: A fragmentação florestal é uma das principais causas da perda de espécies. Avaliamos a extinção local de aves frugívoras de médio e grande porte em seis fragmentos do norte do Paraná: o Parque Estadual Mata dos Godoy (PEMG), maior e mais preservado remanescente florestal da região, e outros cinco fragmentos. Foram realizadas amostragens por pontos de escuta de distância limitada e por transecções no PEMG ao longo de 10 dias: entre setembro de 2010 e março de 2011, e entre agosto e novembro de 2011. Os outros cinco fragmentos foram amostrados ao longo de quatro dias entre outubro e dezembro de 2011. Os dados foram comparados com um levantamento prévio realizado há 10 anos. Não foram observadas extinções no PEMG. No entanto, foram observadas alterações significativas na abundância relativa das espécies em dez anos (Wilcoxon Signed-Rank). Nos outros fragmentos florestais verificou-se o desaparecimento de pelo menos duas espécies, sendo que a variação foi de duas a sete espécies. A proteção do PEMG parece ser crucial para a manutenção das populações de aves frugívoras na paisagem estudada. Palavras-chave: fragmentação florestal, aves frugivoras de grande porte, débito de extinção.

\section{Introduction}

Large frugivorous birds that inhabit forests are often among the first species to disappear in fragmented landscapes (e.g. Willis 1979, Aleixo \& Vielliard 1995, Galetti \& Aleixo 1998, Anjos 2006, Lees \& Peres 2008). Ecological traits and requirements such as low density, low fecundity, spatio-temporal variability of food resources, matrix avoidance and area sensitivity increase their vulnerability in fragmented landscapes (Franklin 1980, Strahl \& Grajal 1991, Galetti \& Pizo 1996, Lynch \& Lande 1998, Ragusa-Netto 2010). However, a recent review indicated that when forest fragments differ little the impact of forest fragmentation on frugivorous birds is lower than expected (Bregman et al. 2014). Declines in populations of frugivorous birds may have implications for the biotic integrity of forest fragments due to their ecological function as seed dispersers (Schupp et al. 2002, Terborgh et al. 2002, Galetti et al. 2013). Indeed, if the persistence of frugivorous populations is higher than expected, their role as seed dispersers is crucial for certain plant species (those which depend on birds for dispersal) occupying isolated forest fragments.

Local extinction often occur after a time lag, which makes the evaluation of population persistence more difficult. In several studies, populations may persist on the brink of extinction for long periods before finally becoming extinct (Brooks et al. 1999, Helm et al. 2006, Vellend et al. 2006). This time lag in extinction is called relaxation time (Diamond 1972). Isolated patches of habitat in fragmented or degraded habitats are said to owe an extinction debt for the species for which future extinctions are inevitable (Tilman et al. 1994, Kuussaari 
et al. 2009). Thus, the mere presence of frugivorous bird species in a forest fragment is no guarantee that the populations will remain in the long-term (Metzger et al. 2009). In this study, we made a preliminary evaluation of the population persistence of large frugivorous birds in forest fragments based on a temporal data series.

Herein we evaluated if large frugivorous birds persisted in six forest fragments in southern Brazil over a period of 10 years. In this case we evaluated only the persistence of the species, not variations in population size. In the largest of those forest fragments, we effectively evaluated variations in the population sizes of the frugivorous birds over the period of 10 years.

\section{Material and Methods}

\section{Study area}

The study was carried out in the Parque Estadual Mata dos Godoy (PEMG) and five other forest fragments (FA, FB, FC, $\mathrm{FH}$ and FI) in the north of Paraná State, southern Brazil (Fig. 1). The region is characterized by a humid subtropical climate (Köppen Cfa) with rainfall concentrated in the summer months and annual average temperature and precipitation of $20.8-21.6^{\circ} \mathrm{C}$ and of $1100-1200 \mathrm{~mm}$, respectively (Maack 1981). The soils have the same parent material (basalt), resulting in fertile reddish clay soils such as eutropherric red latosols (Maack 1981).

The fragmentation process occurred in the studied region about 50 years ago and reduced the forest to small and isolated fragments immersed in a matrix mainly composed by agriculture. In such a scenario of habitat loss, PEMG remains relatively undisturbed and is considered the largest and best preserved area of semideciduous forest in northern Paraná State with a high biological integrity (Anjos et al. 2009). The other fragments vary in size and isolation levels (Table 1). In a recent study assessing the ecological integrity of Atlantic forest remnants, Medeiros \& Torezan (2013) evaluated two of the six areas sampled in this study. According to the authors, the vegetation of the PEMG is of "excellent" integrity category and the vegetation of the fragment FI was classified as "regular". Furthermore, hunting and selective tree logging are forbidden in the region, in particular in the PEMG and in the five forest fragments located in private areas.

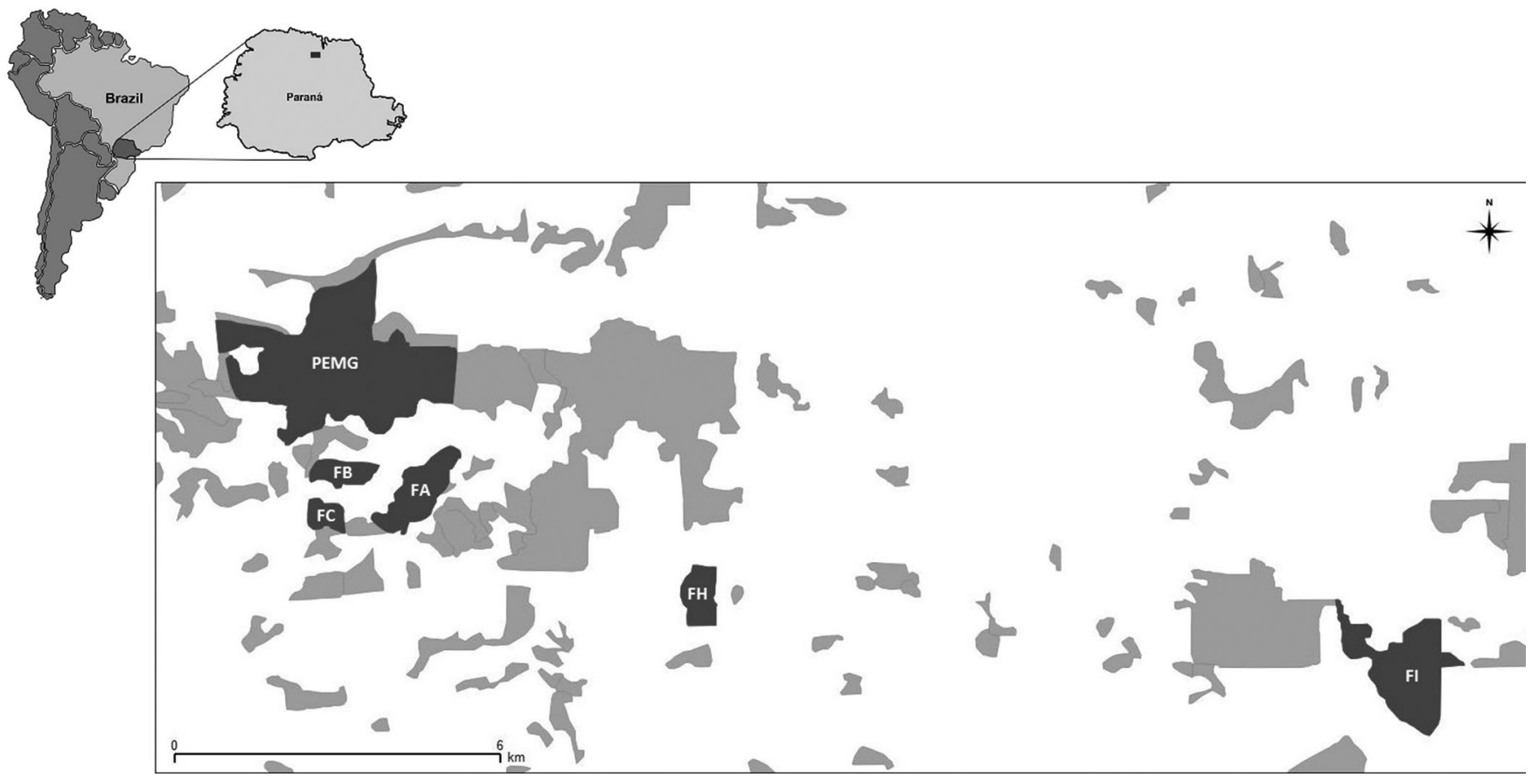

Figure 1. Location of studied areas in Londrina, Parana, Southern Brazil. Studied fragments are presented in dark grey, fragments in light grey and agricultural areas in white. Geographical coordinates are presented in Table 01.

Table 1. Characterization of forest fragments (FF) analyzed by their geographic coordinates, area (ha), connectivity, distance to the PEMG, and proximity index, a proxy for functional connectivity.

\begin{tabular}{llclrr}
\hline FF & \multicolumn{1}{c}{ Geographic coordinates } & Area (ha) & Connectivity & Distance & Proximity index \\
\hline PEMG & $23^{\circ} 27^{\prime} 9,39^{\prime \prime} \mathrm{S} 51^{\circ} 15^{\prime} 17,77^{\prime \prime} \mathrm{W}$ & 656 & Referential & 0 & 125.96 \\
FA & $23^{\circ} 28^{\prime} 8,14^{\prime \prime} \mathrm{S} 51^{\circ} 14^{\prime} 19,85^{\prime \prime} \mathrm{W}$ & 56 & FC & $500 \mathrm{~m}$ & 166.12 \\
FB & $23^{\circ} 28^{\prime} 6,31^{\prime \prime} \mathrm{S} 51^{\circ} 15^{\prime} 17,10^{\prime \prime} \mathrm{W}$ & 25 & PEMG & $400 \mathrm{~m}$ & 133.89 \\
FC & $23^{\circ} 28^{\prime} 31,27^{\prime \prime} \mathrm{S} 51^{\circ} 15^{\prime} 22,17^{\prime \prime} \mathrm{W}$ & 11 & FB & $1100 \mathrm{~m}$ & 199.17 \\
FH & $23^{\circ} 29^{\prime} 17,95^{\prime \prime} \mathrm{S} 51^{\circ} 11^{\prime} 38,35^{\prime \prime} \mathrm{W}$ & 72 & - & $1400 \mathrm{~m}$ & 8.39 \\
FI & $23^{\circ} 30^{\prime} 11,35^{\prime \prime} \mathrm{S} 51^{\circ} 4^{\prime} 34,74^{\prime \prime} \mathrm{W}$ & 184 & - & $14500 \mathrm{~m}$ \\
\hline
\end{tabular}

Proximity index used a search radius of 1000 meters. 
We calculated the proximity index (Uezu et al. 2008) based on a binary forest vs. matrix map obtained from SOS Mata Atlântica (2008) and used by Ribeiro et al. (2009). This index was calculated for the search radius of 1000 meters around a centroid defined within the patches by using ArcGIS (ERSI 2005) and V-LATE extension (LARG 2005). The six forest fragments vary greatly in size and functional connectivity represented by the proximity index (Table 1).

\section{Field work}

2.1 Previous data. Data from two different studies (Anjos 2001, Anjos et al. 2004) conducted in the six forest fragments were used to evaluate the extinction debt of medium and large frugivorous bird species. Data from both studies were obtained using point counts of unlimited distance (Blondel et al. 1970, Vielliard \& Silva 1990). In these studies, the points were $100 \mathrm{~m}$ apart and at least $50 \mathrm{~m}$ from the edge of forest; the sampling time at each point was 20 minutes.

Data presented in Anjos (2001) were collected monthly from January to December 1996 in the PEMG and fragments FA, FB and FC, totaling 12 samples for each fragment. Data presented in Anjos et al. (2004) were collected monthly between September and December 1997 in the PEMG, FA, FB, and FC, and over the same months in 2000 in FH and FI, totaling four samples for each fragment.

2.2 Recent data. The field data were obtained using the methods described in Anjos et al. (2007). Point counts of fixed radius and distance sampling-line transects were sampled along four $1000 \mathrm{~m}$ long trails (TA, TB, TC and TD) in PEMG. For data collected using point counts of limited distance, nine points were established every $100 \mathrm{~m}$ on each trail in the PEMG. Thus, 36 sampling points were sampled over 10 days beginning at sunrise, from September 2010 to March 2011 and from August to November 2011. The detection radius at each point was $50 \mathrm{~m}$ and the starting point for each transect sample alternated each day, offering the same odds of detection for all species. The sampling period at each point was 15 minutes, thus the total sampling on each day lasted for about four hours. Point counts do not consider differences in detectability or make it possible to calculate the current densities of each species; however, this method can be used as an index to detect significant differences in the abundance of populations of a particular species (Bibby et al. 1992). At each sampling point, each pair or flock of each species was counted once, and precautions were taken not to count the same individual or group more than once (Anjos et al. 2011), making it possible to calculate the Index of Point Abundance (IPA) of each species.

For the distance sampling-line transects, the trails in PEMG were traveled at a constant speed of $2 \mathrm{~km} / \mathrm{h}$, allowing the observer to record species through auditory or visual contact at a distance of $50 \mathrm{~m}$. The distance of the bird relative to the observer and the detection angle in relation to the track were measured for subsequent calculation of the relative density for each species. Ten samples per transect from September 2010 to March 2011 were collected, and from August to November 2011, beginning at sunrise to coincide with the beginning of vocal activities of diurnal birds (Gilardi \& Munn 1998). In the case of the Psittacidae family, whenever a flock was sighted, the number of individuals was counted visually. Based on the monitored flocks, an average number of individuals per flock of each Psittacidae species was measured giving an estimation of the number of individuals in the PEMG.

In the five forest fragments (FA, FB, FC, FH and FI) we exclusively used the distance sampling-technique with line transects along $1000 \mathrm{~m}$ long trails. Each fragment was sampled over a period of 4 days between October and December 2011, to verify the presence or absence of frugivorous birds. Thus, the sampling effort was similar to the lower sampling effort of previous studies carried out 10 years ago, allowing the comparison of the occurrence data in each fragment.

\section{Data analysis}

Only medium (40-80 g) and large (greater than $80 \mathrm{~g}$ ) nonpasserines frugivorous birds were considered for this study (Pizo 2001). According to Anjos (2001), 24 medium and large non-passerines frugivorous bird species occur in the PEMG. In this study, these species has been treated as large frugivorous birds.

The population density per hectare in the PEMG was estimated by entering data collected in the sampling-line transect into the software DISTANCE 6.0 (Thomas et al. 2010). We also calculated IPA of each species in the PEMG (according to Anjos et al. 2010) and this value was used to analyze the persistence of these populations after 10 years. The IPA was estimated by dividing the total number of species observed by the total number of points sampled in the PEMG. Wilcoxon SignedRank analysis was used to compare the IPA values of the species obtained in the present study with those presented for the same species a decade earlier by Anjos et al. (2004). This analysis was carried out using the function wilcox with the $\mathrm{R}$ software version 3.0.2 (R Development Core Team 2013).

\section{Results}

Twenty-four species of medium and large frugivorous birds were recorded in the PEMG. Of the 20 species of frugivorous birds recorded by Anjos (2001) and Anjos et al. (2004) in the remaining fragments, 11 species disappeared in some of the forest fragments. However, the rate of species that persisted was different in the forest fragments: $87 \%$ in $\mathrm{FA} ; 75 \%$ in FB; $81 \%$ in FC; $72 \%$ in $\mathrm{FH}$ and $59 \%$ in FI (Table 2). There were also some species that had not been recorded in the survey 10 years ago: one species in FA and FC (Aratinga auricapillus) and three species in FB (Aratinga auricapillus, Psittacara leucophthalmus and Amazona aestiva; see Table 2).

The Wilcoxon Signed-Rank analysis revealed that the IPA values of the analyzed large frugivorous birds changed over 10 years $(\mathrm{V}=285 ; \mathrm{p}=0.0001)$. This difference was also found for the 11 species which disappeared from the fragments, but persisted in the PEMG $(\mathrm{V}=56 ; \mathrm{p}=0.0453)$, and for the remaining 13 species that persisted in the fragments, beside PEMG (V = 90; $p=0.0004)$. In fact, we found that the mean IPA values in 2004 were higher for all those three groups of species than in the present study. When considering all species, the mean IPA in 2004 was 0.3833 while the present mean IPA was 0.0689 . When considering the 11 species that disappeared from the fragments, but persisted in the PEMG, the mean IPA in 2004 was 0.1409 while the present mean IPA was only 0.0116 . Finally, when considering the remaining 13 species that persisted in the fragments, the mean IPA in 2004 was 0.5885 while the present mean IPA was only 0.1173 . 
Table 2. Presence/absence of medium and large frugivorous birds species in fragments analyzed (PEMG, FA, FC, FB, FH and FI) in the present study and 10 years ago (Anjos 2001, Anjos et al. 2004) (X: present species; -: absent species). Species are in systematic and phylogenetic position following nomenclature of the South American Classification Committee of the American Ornithologists' Union (Remsen et al. 2015).

\begin{tabular}{|c|c|c|c|c|c|c|c|c|c|c|c|c|}
\hline \multirow[b]{2}{*}{ Species } & \multicolumn{6}{|c|}{ Present study } & \multicolumn{6}{|c|}{ Previous study } \\
\hline & PEMG & FA & FB & FC & FH & FI & PEMG & FA & FB & FC & FH & FI \\
\hline \multicolumn{13}{|l|}{ Cracidae } \\
\hline Penelope superciliaris Temminck, 1815 & $\mathrm{X}$ & - & $\mathrm{X}$ & $\mathrm{X}$ & $\mathrm{X}$ & - & $\mathrm{X}$ & $\mathrm{X}$ & $\mathrm{X}$ & $\mathrm{X}$ & $\mathrm{X}$ & $\mathrm{X}$ \\
\hline \multicolumn{13}{|l|}{ Columbidae } \\
\hline Claravis pretiosa (Ferrari-Pérez, 1886) & $\mathrm{X}$ & - & - & - & - & - & $\mathrm{X}$ & - & - & - & $\mathrm{X}$ & $\mathrm{X}$ \\
\hline Patagioenas picazuro Temminck, 1813 & $\mathrm{X}$ & $\mathrm{X}$ & $\mathrm{X}$ & $\mathrm{X}$ & $\mathrm{X}$ & $\mathrm{X}$ & $\mathrm{X}$ & $\mathrm{X}$ & $\mathrm{X}$ & $\mathrm{X}$ & $\mathrm{X}$ & $\mathrm{X}$ \\
\hline Patagioenas cayennensis Bonnaterre, 1792 & $\mathrm{X}$ & $\mathrm{X}$ & $\mathrm{X}$ & $\mathrm{X}$ & $\mathrm{X}$ & $\mathrm{X}$ & $\mathrm{X}$ & $\mathrm{X}$ & $\mathrm{X}$ & $\mathrm{X}$ & $\mathrm{X}$ & $\mathrm{X}$ \\
\hline Patagioenas plumbea Vieillot, 1818 & $\mathrm{X}$ & - & - & - & - & - & $\mathrm{X}$ & - & - & - & - & - \\
\hline Leptotila verreauxi Bonaparte, 1855 & $\mathrm{X}$ & $\mathrm{X}$ & $\mathrm{X}$ & $\mathrm{X}$ & $\mathrm{X}$ & $\mathrm{X}$ & $\mathrm{X}$ & $\mathrm{X}$ & $\mathrm{X}$ & $\mathrm{X}$ & $\mathrm{X}$ & $\mathrm{X}$ \\
\hline Leptotila rufaxilla (Richard \& Bernard, 1792) & $\mathrm{X}$ & $\mathrm{X}$ & $\mathrm{X}$ & $\mathrm{X}$ & $\mathrm{X}$ & - & $\mathrm{X}$ & $\mathrm{X}$ & $\mathrm{X}$ & $\mathrm{X}$ & $\mathrm{X}$ & $\mathrm{X}$ \\
\hline Geotrygon montana (Linnaeus, 1758) & $\mathrm{X}$ & $\mathrm{X}$ & $\mathrm{X}$ & $\mathrm{X}$ & $\mathrm{X}$ & - & $\mathrm{X}$ & $\mathrm{X}$ & $\mathrm{X}$ & $\mathrm{X}$ & $\mathrm{X}$ & $\mathrm{X}$ \\
\hline \multicolumn{13}{|l|}{ Trogonidae } \\
\hline Trogon surrucura Vieillot, 1817 & $\mathrm{X}$ & $\mathrm{X}$ & $\mathrm{X}$ & $\mathrm{X}$ & $\mathrm{X}$ & $\mathrm{X}$ & $\mathrm{X}$ & $\mathrm{X}$ & $\mathrm{X}$ & $\mathrm{X}$ & $\mathrm{X}$ & $\mathrm{X}$ \\
\hline Trogon rufus Gmelin, 1788 & $\mathrm{X}$ & - & - & - & - & - & $\mathrm{X}$ & - & - & - & - & $\mathrm{X}$ \\
\hline \multicolumn{13}{|l|}{ Momotidae } \\
\hline Baryphthengus ruficapillus (Vieillot, 1818) & $\mathrm{X}$ & $\mathrm{X}$ & $\mathrm{X}$ & $\mathrm{X}$ & $\mathrm{X}$ & $\mathrm{X}$ & $\mathrm{X}$ & $\mathrm{X}$ & $\mathrm{X}$ & $\mathrm{X}$ & $\mathrm{X}$ & $\mathrm{X}$ \\
\hline \multicolumn{13}{|l|}{ Ramphastidae } \\
\hline Ramphastos dicolorus Linnaeus, 1766 & $\mathrm{X}$ & - & - & - & - & - & $\mathrm{X}$ & $\mathrm{X}$ & $\mathrm{X}$ & $\mathrm{X}$ & $\mathrm{X}$ & - \\
\hline Selenidera maculirostris (Lichtenstein, 1823) & $\mathrm{X}$ & $\mathrm{X}$ & $\mathrm{X}$ & $\mathrm{X}$ & $\mathrm{X}$ & $\mathrm{X}$ & $\mathrm{X}$ & $\mathrm{X}$ & $\mathrm{X}$ & $\mathrm{X}$ & $\mathrm{X}$ & $\mathrm{X}$ \\
\hline Pteroglossus bailloni (Vieillot, 1819) & $\mathrm{X}$ & - & - & - & - & - & $\mathrm{X}$ & - & - & - & - & $\mathrm{X}$ \\
\hline Pteroglossus aracari (Linnaeus, 1758) & $\mathrm{X}$ & - & - & - & - & - & $\mathrm{X}$ & - & - & - & - & - \\
\hline \multicolumn{13}{|l|}{ Psittacidae } \\
\hline Primolius maracana (Vieillot, 1816) & $\mathrm{X}$ & - & - & - & - & - & $\mathrm{X}$ & - & - & $\mathrm{X}$ & - & - \\
\hline Psittacara leucophthalmus (Müller, 1776) & $\mathrm{X}$ & $\mathrm{X}$ & $\mathrm{X}$ & - & $\mathrm{X}$ & $\mathrm{X}$ & $\mathrm{X}$ & - & $\mathrm{X}$ & - & $\mathrm{X}$ & $\mathrm{X}$ \\
\hline Aratinga auricapillus (Kuhl, 1820) & $\mathrm{X}$ & $\mathrm{X}$ & $\mathrm{X}$ & - & $\mathrm{X}$ & - & $\mathrm{X}$ & - & - & - & - & - \\
\hline Pyrrhura frontalis (Vieillot, 1818) & $\mathrm{X}$ & - & $\mathrm{X}$ & - & - & - & $\mathrm{X}$ & $\mathrm{X}$ & $\mathrm{X}$ & $\mathrm{X}$ & $\mathrm{X}$ & $\mathrm{X}$ \\
\hline Brotogeris tirica (Gmelin, 1788) & $\mathrm{X}$ & - & - & - & - & - & $\mathrm{X}$ & - & - & $\mathrm{X}$ & - & - \\
\hline Pionopsitta pileata (Scopoli, 1769) & $\mathrm{X}$ & - & - & - & - & $\mathrm{X}$ & $\mathrm{X}$ & - & - & - & - & $\mathrm{X}$ \\
\hline Pionus maximiliani (Kuhl, 1820) & $\mathrm{X}$ & $\mathrm{X}$ & $\mathrm{X}$ & $\mathrm{X}$ & $\mathrm{X}$ & $\mathrm{X}$ & $\mathrm{X}$ & $\mathrm{X}$ & $\mathrm{X}$ & $\mathrm{X}$ & $\mathrm{X}$ & $\mathrm{X}$ \\
\hline Amazona aestiva (Linnaeus, 1758) & $\mathrm{X}$ & $\mathrm{X}$ & - & - & $\mathrm{X}$ & - & $\mathrm{X}$ & - & $\mathrm{X}$ & - & $\mathrm{X}$ & - \\
\hline Triclaria malachitacea (Spix, 1824) & $X$ & - & - & - & - & - & $X$ & - & - & - & - & - \\
\hline
\end{tabular}

It was possible to calculate the population density for nine of the 24 sampled species (Table 3; 4). The species with the highest density was Aratinga auricapillus, with $1.04 \mathrm{ind} / \mathrm{ha}$, while the lowest was Patagioenas cayennensis, with 0.231 ind/ha.

\section{Discussion}

The differences found between the values of IPA comparing our recent data with those from ten years ago in the PEMG demonstrates that the effects of forest fragmentation could still have an impact on large frugivorous birds, even in a relatively large forest fragment. Our data suggest that populations of large frugivorous birds could be declining over time in the PEMG. Therefore, the large frugivorous birds in the PEMG may have been paying an extinction debt over the last ten years (Diamond 1972, Tilman et al. 1994, Kuussaari et al. 2009).

Some studies have demonstrated that forest species with large population size in fragmented landscapes tend to persist longer in forest fragments (e.g. Purvis et al. 2000, Manne \& Pimm 2001, Henle et al. 2004), probably due to the rescue effect, which increase the chances to colonize empty fragments (Brown \& Kodric-Brown 1977, Anjos et al. 2011). This argument is consistent with our data on the 11 species that were not recorded in at least one of the closer fragments; those species reached the lowest IPA values in the PEMG. Therefore, low population size seems to reduce the potential of the rescue effect of large frugivorous birds from surrounding forest fragments. If it is true, those 11 species could be considered as members of the "undead" sensu Sodhi et al. (2011), even in the PEMG. Interestingly, the FI fragment that presented the highest proximity index (499.1), also lost the highest number of species. This unexpected result could be explained by the fact that FI is the farthest studied fragment from the PEMG which probably acts as an important source for rescue effects in that landscape. Furthermore, all the forest fragments located within 2400 meters radius from PEMG lost fewer species (two to four species), while FI, which is located 14.500 meters far from PEMG, lost seven species.

Some studies have demonstrated the negative effect of the extinction of large frugivorous birds in forest dynamics (e.g. Silva \& Tabarelli 2000, Lord et al. 2002, Schupp et al. 2002, Terborgh et al. 2002, Galetti et al. 2013). Galetti et al. (2013), in a recent study conducted in the Brazilian Atlantic forest showed that functional extinction of large frugivorous birds is associated with the consistent reduction of Euterpe edulis' seed size resulting in several negative consequences for plant recruitment 
Table 3. Index of Point Abundance (IPA) of medium and large frugivorous bird species from PEMG in the present study and 10 years ago (Anjos et al. 2004). Species are in systematic and phylogenetic position following nomenclature of the South American Classification Committee of the American Ornithologists' Union (Remsen et al. 2015).

\begin{tabular}{|c|c|c|}
\hline & \multicolumn{2}{|c|}{ IPA } \\
\hline & Present study & Previous study \\
\hline \multicolumn{3}{|l|}{ Cracidae } \\
\hline Penelope superciliaris Temminck, 1815 & 0.006 & 0.200 \\
\hline \multicolumn{3}{|l|}{ Columbidae } \\
\hline Claravis pretiosa (Ferrari-Pérez, 1886) & 0.003 & 0.000 \\
\hline Patagioenas picazuro Temminck, 1813 & 0.264 & 1.850 \\
\hline Patagioenas cayennensis Bonnaterre, 1792 & 0.086 & 0.450 \\
\hline Patagioenas plumbea Vieillot, 1818 & 0.003 & 0.000 \\
\hline Leptotila verreauxi Bonaparte, 1855 & 0.247 & 0.950 \\
\hline Leptotila rufaxilla (Richard \& Bernard, 1792) & 0.008 & 0.050 \\
\hline Geotrygon montana (Linnaeus, 1758) & 0.031 & 0.200 \\
\hline \multicolumn{3}{|l|}{ Trogonidae } \\
\hline Trogon surrucura Vieillot, 1817 & 0.194 & 0.900 \\
\hline Trogon rufus Gmelin, 1788 & 0.014 & 0.000 \\
\hline \multicolumn{3}{|l|}{ Momotidae } \\
\hline Baryphthengus ruficapillus (Vieillot, 1818) & 0.142 & 0.550 \\
\hline \multicolumn{3}{|l|}{ Ramphastidae } \\
\hline Ramphastos dicolorus Linnaeus, 1766 & 0.008 & 0.350 \\
\hline Selenidera maculirostris (Lichtenstein, 1823) & 0.236 & 0.900 \\
\hline Pteroglossus bailloni (Vieillot, 1819) & 0.017 & 0.000 \\
\hline Pteroglossus aracari (Linnaeus, 1758) & 0.006 & 0.050 \\
\hline \multicolumn{3}{|l|}{ Psittacidae } \\
\hline Primolius maracana (Vieillot, 1816) & 0.008 & 0.200 \\
\hline Psittacara leucophthalmus (Müller, 1776) & 0.114 & 0.200 \\
\hline Aratinga auricapillus (Kuhl, 1820) & 0.131 & 0.750 \\
\hline Pyrrhura frontalis (Vieillot, 1818) & 0.003 & 0.450 \\
\hline Brotogeris tirica (Gmelin, 1788) & 0.014 & 0.000 \\
\hline Pionopsitta pileata (Scopoli, 1769) & 0.014 & 0.150 \\
\hline Pionus maximiliani (Kuhl, 1820) & 0.086 & 0.750 \\
\hline Amazona aestiva (Linnaeus, 1758) & 0.017 & 0.100 \\
\hline Triclaria malachitacea (Spix, 1824) & 0.003 & 0.150 \\
\hline
\end{tabular}

Table 4. Population density per hectare (D) of nine species recorded in PEMG. For the families Columbidae, Trogonidae, Momotidae and Ramphastidae, values are number of pairs per ha, while for Psittacidae values are number of individuals per ha. Species are in systematic and phylogenetic position following nomenclature of the South American Classification Committee of the American Ornithologists' Union (Remsen et al. 2015).

\begin{tabular}{|c|c|c|}
\hline Species & D & Individual/band \\
\hline \multicolumn{3}{|l|}{ Columbidae } \\
\hline Patagioenas picazuro (Temminck, 1813) & 0.928 & \\
\hline Patagioenas cayennensis (Bonnaterre, 1792) & 0.231 & \\
\hline Leptotila verreauxi Bonaparte, 1855 & 0.439 & \\
\hline \multicolumn{3}{|l|}{ Trogonidae } \\
\hline Trogon surrucura Vieillot, 1817 & 0.341 & \\
\hline \multicolumn{3}{|l|}{ Momotidae } \\
\hline Baryphthengus ruficapillus (Vieillot, 1818) & 0.415 & \\
\hline \multicolumn{3}{|l|}{ Ramphastidae } \\
\hline Selenidera maculirostris (Lichtenstein, 1823) & 0.781 & \\
\hline \multicolumn{3}{|l|}{ Psittacidae } \\
\hline Psittacara leucophthalmus (Statius Müller, 1776) & 0.976 & $4,67 \pm 3,18(\mathrm{n}=33)$ \\
\hline Aratinga auricapillus (Kuhl, 1820) & 1.040 & $4,28 \pm 2,01(\mathrm{n}=40)$ \\
\hline Pionus maximiliani (Kuhl, 1820) & 0.528 & $3,00 \pm 1,24(\mathrm{n}=27)$ \\
\hline
\end{tabular}


and population dynamics. Penelope superciliaris, the frugivorous bird species with the largest body mass recorded in PEMG and a major disperser of E. edulis was not found either in the smallest (FB) or in the most isolated (FI) fragments. The level of isolation and the size of the fragments, which among other factors are related to the population decline or local extinction of large frugivorous birds, may be associated with functional loss of these species and its consequences to the ecosystem.

It is important to mention, however, that time difference between the two studies are relatively short (a decade) and such fluctuations could be expected in the seasonal semidecidous forest. Indeed, we do not know about the natural fluctuations of those frugivorous populations over time. For example, if resources were scarce in those particular fragments due to climatic variations in recent years, the occurrence and abundance of the studied birds could be affected. Another aspect that could affect time lag studies is the potential alterations of the matrix habitat due to anthropogenic action. Although the landscape appeared similar during the studied period, it is unclear whether some disturbance, in particular in the matrix habitat, could have affected our data. Therefore, our results should be viewed as a preliminary investigation of the effects of fragmentation over time. Only a long term monitoring campaign over a higher number of forest fragments could uncover bird population trends in the studied landscape.

We also recorded three species of Psittacidae, Aratinga auricapillus, Psittacara leucophthalmus and Amazona aestiva in three fragments of the five analyzed fragments (FA, FB and FC) in the latest survey. Unlike the remaining frugivores, Psittacidae have a high capacity for dispersal across open spaces, using a wide area throughout the day (Gilardi \& Munn 1998, Lees \& Peres 2009). It is important to mention that $A$. auricapillus is Near Threatened according to BirdLife International (2013), which could highlight the importance of the PEMG for conservation of this particular species.

In conclusion, our study indicates that forest fragmentation could be negatively influencing the persistence of the remaining populations of large frugivorous birds in the studied fragmented landscapes. Therefore, protecting the PEMG with buffer zones for restoration, as well as increasing connectivity with surrounding forest fragments with forest corridors is crucial for maintenance of frugivorous populations in the studied landscape.

\section{Acknowledgments}

We are grateful to Edmilson Bianchini, José Flávio Cândido Júnior and Marco Aurélio Pizo for revising a previous version of the manuscript. We thank the Universidade Estadual de Londrina for logistical support, the Instituto Ambiental do Paraná (255/10) for permission to conduct research in the Godoy State Park and the owners of the private lands where some sites are located for permission to conduct our studies. We also thank the editors and the referees who helped us to improve substantially the manuscript.

\section{References}

ALEIXO, A. \& VIELLIARD, J.M.E. 1995. Composição e dinâmica da comunidade de aves da Mata de Santa Genebra, Campinas, SP. Rev Bras Zool 12(3):493-511.

ANJOS, L. 2001. Bird communities in five Atlantic forest fragments in southern Brazil. Ornitol Neotrop 12:11-27.
ANJOS, L. 2006. Bird species sensitivity in a fragmented landscape of the Atlantic Forest Southern Brazil. Biotropica 32(2):229-234.

ANJOS, L., ZANETTE, L. \& LOPES, E.V. 2004. Effects of fragmentation on bird guilds of the Atlantic forest in north Paraná, southern Brazil. Ornitol Neotrop 15:137-144.

ANJOS, L., VOLPATO, G.H., LOPES, E.V., SERAFINI, P.P., POLETTO, F. \& ALEIXO, A. 2007. The importance of riparian forest for the maintenance of bird species richness in an Atlantic Forest remnant, southern Brazil. Rev Bras Zool 24(4):1078-1086.

ANJOS, L., BOCHIO, G.M., CAMPOS, J.V., McCRATE, G.B. \& PALOMINO, F. 2009. Sobre o uso de níveis de sensibilidade de aves à fragmentação florestal na avaliação da Integridade Biótica: um estudo de caso no norte do Estado do Paraná, sul do Brasil. Revista Brasileira de Ornitologia, 17:28-36.

ANJOS, L., HOLT, R.D. \& ROBINSON, S. 2010. Position in the distributional range and sensitivity to forest fragmentation in birds: a case history from the Atlantic forest, Brazil. Bird Conserv Int 20(4):392-399.

ANJOS, L., COLlins, C.D., HOLT, R.D., VOLPATO, G.H., MENDONÇA, L.B., LOPES, E.V., BOÇON, R., BISHEIMER, M.V., SERAFINI, P.P. \& CARVALHO, J. 2011. Bird species abundance-occupancy patterns and sensitivity to forest fragmentation: implications for conservation in the Brazilian Atlantic forest. Biol Conserv 144(9):2213-2222.

BIBBY, C.J., BURGESS, N.D. \& HILL, D.A. 1992. Bird Census Techniques. Academic Press, San Diego.

BirdLife International. 2013. Species factsheet: Aratinga auricapillus. Downloaded from http://www.birdlife.org on 06/12/2013.

BLONDEL, J., FERRY, C. \& FROCHOT, B. 1970. La méthode des indices ponctuels d'abondance (I.P.A.) ou des relevés d'avifaune par "stations d'écoute"; Alauda 38:55-71.

BREGMAN, T.P., SEKERCIOGLU, C.H., TOBIAS, J.A. 2014. Global patterns and predictors of bird species responses to forest fragmentation: Implications for ecosystem function and conservation. Biol Conserv 169:372-383.

BROOKS, T., TOBIAS, J. \& BALMFORD, A. 1999. Deforestation and bird extinctions in the Atlantic Forest. Anim Conserv 2(3): 211-222.

BROWN, J. H. \& KODRIC-BROWN, A. (1977). Turnover rates in insular biogeography: effect of immigration on extinction. Ecology 58(2):445-449.

DIAMOND, J.M. 1972. Biogeographic kinetics: estimation of relaxation times for avifaunas of Southwest Pacific Islands. P Natl Acad Sci USA 69(11):3199-3203.

ERSI (Environmental Systems Research Institute). 2005. ArcGIS Desktop: Release 8. Environmental Systems Research Institute, Redlands, CA.

FRANKLIN, I.R. 1980. Evolutionary change in small populations. In Conservation biology: an evolutionary-ecological perspective. (SOULÉ, M.E. \& WILCOX, eds). Sinauer Associates, Massachusetts, p.135-150.

GALETTI, M. \& PIZO, M.A. 1996. Fruit eating by birds in a forest fragment in southeastern Brazil. Ararajuba 4(2):71-79.

GALETTI, M. \& ALEIXO, A. 1998. Effects of palm heart harvesting on avian frugivores in the Atlantic rain forest of Brazil. J App Ecol 35:286-293.

GAletTI, M., GUEVARA, R., CÔRTES, M.C., FADINI, R., VON MATTER, S, LEITA, A.B, LABECCA, F, RIBEIRO, T, CARVALHO, C.S, COLLEVATTI, R.G, PIRES, M.M, GUIMARÃES, P.R JR., BRANCALION, P.H., RIBEIRO, M.C. \& JORDANO, P. 2013. Functional Extinction of Birds Drives Rapid Evolutionary Changes in Seed Size. Science 340(6136):1086-1090.

GILARDI, J.D. \& MUNN, C.A. 1998. Patterns of activity, flocking, and habitat use in parrots of the Peruvian Amazon. Condor 100(4):641-653.

HELM, A., HANSKI, I. \& PÄRTEL, M. 2006. Slow response of plant species richness to habitat loss and fragmentation. Ecol Lett 9: 72-77. 
HENLE, K., DAVIES, K.F., KLEYER, M., MARGULES, C. \& SETTELE, J. 2004. Predictors of species sensitivity to fragmentation. Biodivers Conserv 13:207-251.

KUUSSAARI, M., BOMMARCO, R., HEIKKINEN, R.K., HELM, A., KRAUSS, J., LINDBORG, R., OCKINGER, E., PARTEL, J., RODÀ, F., STEFANESCU, C., TEDER, T., ZOBEL, M. \& STEFFAN-DEWENTER, L. 2009. Extinction debt: a challenge for biodiversity conservation. Trends Ecol Evol 24(10): 564-571.

LARG (Landscape and Resource Management Research Group). 2005. V-LATE - Vector-based Landscape Analysis Tools Extension. Available from URL: https://sites.google.com/site/largvlate/ gis-tools/v-late (Last access on 31/01/2007)

LEES, A.C. \& PERES, C.A. 2008. Avian Life history determinants of local extinction risk in a fragmented neotropical forest landscape. Anim Conserv 11(2):128-137.

LEES, A.C. \& PERES, C.A. 2009. Gap-crossing movements predict species occupancy in Amazonian forest fragments. Oikos 118 (2):280-290

LORD, J.M., MARKEY, A.S. \& MARSHALL, J. 2002. Have frugivores influenced the evolution of fruit traits in New Zealand? In Seed Dispersal and Frugivory: Ecology, Evolution and Conservation. (LEVEY, D.J., SILVA, W.R. \& GALETTI, M. eds). CAB Internacional, Oxford, p.55-68.

LYNCH, M. \& LANDE, M. 1998. The critical effective size for a genetically secure population. Anim Conserv 1(1):70-72.

MAACK, R. 1981. Geografia Física do Paraná. José Olympio, Curitiba.

MANNE, L.L. \& PIMM, S.L. 2001. Beyond eight forms of rarity: which species are threatened and which will be next? Anim Conserv 4(3):221-229.

MEDEIROS, H.R., TOREZAN, J.M. 2013. Evaluating the ecological integrity of Atlantic forest remnants by using rapid ecological assessment. Environ Monit Assess 185:4373-4382.

METZGER, J.P., MARTENSEN, A.C., DIXO, M., BERNACCI, L.C., RIBEIRO, M.C., TEIXEIRA, A.M.G., PARDINI, R. 2009. Time-lag in biological responses to landscape changes in a highly dynamic Atlantic forest region. Biol Conserv 142:1166-1177.

PIZO, M.A. 2001. A conservação das aves frugívoras. In Ornitologia e conservação: da ciência às estratégias. (ALBUQUERQUE, J.L., CÂNDIDO-JUNIOR, J.F., STRAUBE, F.C. \& ROOS, A. eds). Editora Unisul, Tubarão, p.49-59.

PURVIS, A., JONES, K.E. \& MACE, G.M. 2000. Extinction. BioEssays 22(12):1123-1133.

R DEVELOPMENT CORE TEAM. 2013. R: A language and environment for statistical computing. R Foundation for Statistical Computing, Vienna.

RAGUSA-NETTO, J. 2010. Figs and the persistence of Toco Toucan (Ramphastos toco) at dry forests from western Brazil. Ornitol Neotrop 21:59-70.
REMSEN Jr, J.V., ARETA, J.I., CADENA, C.D., JARAMILLO, A., NORES, M., PACHECO, J.F., PÉREZ-EMÁN, J., ROBBINS, M.B., STILES, F.G., STOTZ, D.F., \& ZIMMER, K.J. Version 2015. A classification of the bird species of South America. American Ornithologists' Union. http://www.museum.lsu.edu/ $\sim$ Remsen/SACCBaseline.html.

RIBEIRO, M.C., METZGER, J.P., MARTENSEN, A.C., PONZONI, F.J. \& HIROTA, M.M. 2009. The Brazilian Atlantic Forest: How much is left, and how is the remaining forest distributed? Implications for conservation. Biol Conserv 142:1141-1153.

SCHUPP, E.W., MILLERON, T. \& RUSSO, S.E. 2002. Dissemination limitation and the origin and maintenance of species-rich tropical forests. In Seed Dispersal and Frugivory: Ecology, Evolution and Conservation. (LEVEY, D.J., SILVA, W.R. \& GALETTI, M. eds). CAB International, Oxford, p.19-33.

SILVA, J.M.C. \& TABARELLI, M.M. 2000. Tree species impoverishment and the future flora of the Atlantic forest of northeast Brazil. Nature 404:72-74.

SODHI, N.S., SEKERCIOGLU, C.H., BARLOW, J. \& ROBINSON, S.K. 2011. Conservation of Tropical Birds. Wiley-Blackwell, Oxford.

STRAHL, S.D. \& GRAJAL, A. 1991. Conservation of large avian frugivores and the management of Neotropical protected areas. Oryx 25(1):50-55.

TERBORGH, J.N., PITMAN, M., SILMAN, H., SCHICHTER \& NUÑEZ, P.V. 2002. Maintenance of tree diversity in tropical forests. In Seed Dispersal and Frugivory: Ecology, Evolution and Conservation. (LEVEY, D.J., SILVA, W.R. \& GALETTI, M. eds). CAB International, Oxford, p1-18.

THOMAS, L., BUCKLAND, S., TREXSTAD, E.A., LAAKE, J.L., STRINDBERG, S., HEDLEY, S.L., BISHOP, J.R.B, MARQUES, T.A. \& BURNHAM, K.P. 2010. Distance software: design and analysis of distance sampling surveys for estimating population size. J App Ecol 47(1):5-14.

TILMAN, D., MAY, R.M., LEHMAN, C.L. \& NOWAK, A. 1994. Habitat destruction and the extinction debt. Nature 371:65-66.

UEZU, A., BEYER, D.D., METZGER, J.P. 2008. Can agroforest woodlots work as stepping stones for birds in the Atlantic forest region? Biodivers Conserv 17:1907-1922.

VELLEND, M., VERHEYEN, K., JACQUEMYN, H., KOLB, A., VAN CALSTER, H, PETERKEN, G \& HERMY, M. 2006. Extinction debt of forest plants persists for more than a century following habitat fragmentation. Ecology 87(3):542-548.

VIELLIARD, J.M.E. \& SILVA, W.R. 1990. Nova metodologia de levantamento quantitative da avifauna e primeiros resultados do interior do Estado de São Paulo, Brasil. In: Anais do IV Encontro Nacional de Anilhadores de Aves, Recife, p. 117-151.

WILLIS, E.O. 1979. The composition of avian communities in remanescent woodlots in southern Brazil. Papéis Avulsos de Zoologia 33:1-25.

Received 19/06/2014 Revised 4/03/2015 Accepted 11/03/2015 